\title{
線維筋痛症に対し白虎湯加味方が著効した症例
}

\author{
橋本すみれ $\mathrm{a}$ 地野 充時 $\mathrm{b}$ 来村 昌紀 $\mathrm{a}$ \\ 王子 剛 $\mathrm{d}$ 小川 恵子 $\mathrm{a}$ 大野 賢二 $\mathrm{b}$ \\ 平崎 能郎 $\mathrm{c}$ 林 克美 $\mathrm{e}$ 笠原 裕司 $\mathrm{b}$ \\ 関矢 信康 $\mathrm{b}$ 並木 隆雄 $\mathrm{b}$ 寺澤 捷年 $\mathrm{c}$ \\ a 千葉大学医学部附属病院和漢診療科, 千葉， $\overline{7} 260-8677$ 千葉市中央区亥鼻1-8-1 \\ 千葉大学大学院医学研究院先端和漢診療学講座, 千葉, $=260-8670$ 千葉市中央区亥鼻1-8-1 \\ 千葉大学大学院医学研究院和漢診療学講座, 千葉, $=260-8670$ 千葉市中央区亥鼻1-8-1 \\ 鹿島労災病院内科, 茨城, = 314-0343 神栖市土合本町1-9108-2

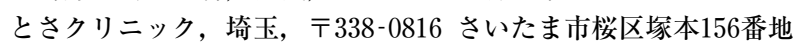

\section{A Case of Generalized Pain from Fibromyalgia Successfully Treated with Byakkoto}

\begin{tabular}{|c|c|c|}
\hline Sumire HA & hi CHINO ${ }^{b}$ & Masaki R \\
\hline Yoshiro H & $\mathrm{SHI}^{\mathrm{e}}$ & $\mathrm{AH}$ \\
\hline Nobuyasu SI & Takao NAMIKI ${ }^{b}$ & i TERASAW \\
\hline
\end{tabular}

a Department of Japanese Oriental (Kampo) Medicine, Chiba University Hospital, 1-8-1 Inohana, Chuo-ku, Chiba 260-8677, Japan

b Department of Frontier Japanese Oriental (Kampo) Medicine, Graduate School of Medicine, Chiba University, 1-8-1 Inohana, Chuo-ku, Chiba 260-8670, Japan

c Department of Japanese Oriental (Kampo) Medicine, Graduate school of Medicine, Chiba University, 1-8-1 Inohana, Chuoku, Chiba 260-8670, Japan

d Department of Internal Medicine, Kashima Rosai Hospital, 1-9108-2 Doaihonchou, Kamisu, Ibaraki 314-0343, Japan

e Tosa Clinic, 156 Tsukamoto, Sakura-ku, Saitama 338-0816, Japan

\begin{abstract}
We report on a case of severe generalized pain due to fibromyalgia syndrome, which was successfully treated with a variation of byakkoto. A 65-year-old Japanese woman had severe generalized pain which grew worse in warm environments, such as during the summer or when bathing. She also had pollakidipsia. We utilized a variation of byakkoto on the assumption that she was suffered from high inner heat. Her severe generalized pain resolved with this therapy. Although bushi-zai and saiko-zai are common prescriptions for fibromyalgia syndrome, byakkoto-variations may also be effective in cases where conditions are worsened by heat effect.

Key words : : fibromyalgia syndrome, byakkoto-variations, heat effect, inner heat

要旨

線維笳痛症による全身の疼痛に対し，白虎湯加味方が有効であった症例を経験した。症例は65歳女性。自覚症状 として, 夏場に，あるいは入浴などで身体が温まると増悪する全身の疼痛および口渴，多飲があり，身熱の甚だし い状態と考えて, 白虎湯加味方を使用したところ全身の疼痛が消失した。線維筋痛症に対する漢方治療は, 附子剤 や柴胡剤が処方される症例が多いが，温熱刺激により全身の疼痛が悪化する症例には白虎湯類が有効である可能性 が示唆された。
\end{abstract}

キーワード : 線維筋痛症, 白虎湯類, 温熱刺激, 身熱

\section{緒言}

線維筋痛症は，30～50歳の女性に多く見られる慢 性の広範囲な筋骨格系の疼痛，こわばり，異常感覚，
睡眠障害，および多発性の圧痛点を伴った易疲労感 を呈する疾患であり, 疼痛の原因として, 中枢神経 系の異常が病因と推測されている。治療には抗うつ 
薬や抗不安薬, NSAIDs, アセトアミノフェンなど の薬物療法やカウンセリング，バイオフォードバッ ク療法, 行動療法, 催眠療法などが行われるが, 奏 効せず症状が慢性化する患者もいるとされている11。

一方, 関節や四肢の疼痛・腫脹・しびれ・重だる さなどを引き起こす病態を漢方医学的には「盘証」 といい, 正気不足が原因となり, 風・寒・湿・熱の 外邪が体表を襲うことによって発生するとされる。 一般的には邪が中心の実証の病態となることが多く, 大きく寒性（風寒湿痺証）と熱性（風湿熱痺証）に 分けられる。したがって, 疩証の治療方剂は社風薬, 散寒薬, 化湿薬, 清熱薬が組み合わせて用いられて いる ${ }^{2)}$ 。

今回我々は，線維筋痛症による全身の疼痛に対し， 白虎湯加味方が有効であった症例を経験したので報 告する。なお，本報告で用いた白虎湯加味方の分量 等詳細は本文の末尾に附記した。

\section{症例}

65歳 女性。

主訴：全身の痛み。

生活歴: 独居。サービス業。酒は機会飲酒, たば こは一日20本。

家族歴: 父 (高血圧・脳卒中), 母 (産後死亡)。

既往歴: 幼少時長崎にて被爆した。2003年带状疮 疹（Th4-5)，2005年高血圧 - 高脂血症 - 脳動静脈 奇形・頸部脊柱管狭窄症・逆流性食道炎・声带ポ リープ手術。

現病歴：1998年頃より両肘痛が出現し，2003年頃 からは頸部痛, 両全指関節痛も出現した。その後, 両肩 ·腕 ・膝 · 大腿部 - 足首に疼痛が拡大し, また その程度も増悪した。2005年近医整形外科にて線維 筋痛症と診断され, 週 2 回の神経ブロックとプレド ニゾロン $5 \mathrm{mg} /$ 日の投与を受けたが，疼痛の範囲も 程度も改善は認められなかった。その後, 莐薬甘草 湯, 桂枝加术附湯, 小建中湯, 黄連解毒湯も投与さ れたが症状に変化なく, 漢方治療を目的に2007年 3 月当科外来を受診した。外来にて疎経活血湯を投与 されたが効果が認められなかったため, 適方検討目 的に同年 5 月当科入院となった。

\section{入院時現代医学的所見}

身長 $151.5 \mathrm{~cm}$, 体重 $53.3 \mathrm{~kg}$, 体温 $36.6^{\circ} \mathrm{C}$, 血圧104/ $60 \mathrm{mmHg}$, 脈拍 $80 /$ 分, $\mathrm{SpO} 296 \%$ 。

図 1 に症例の疼痛の分布を示した。デルマトーム
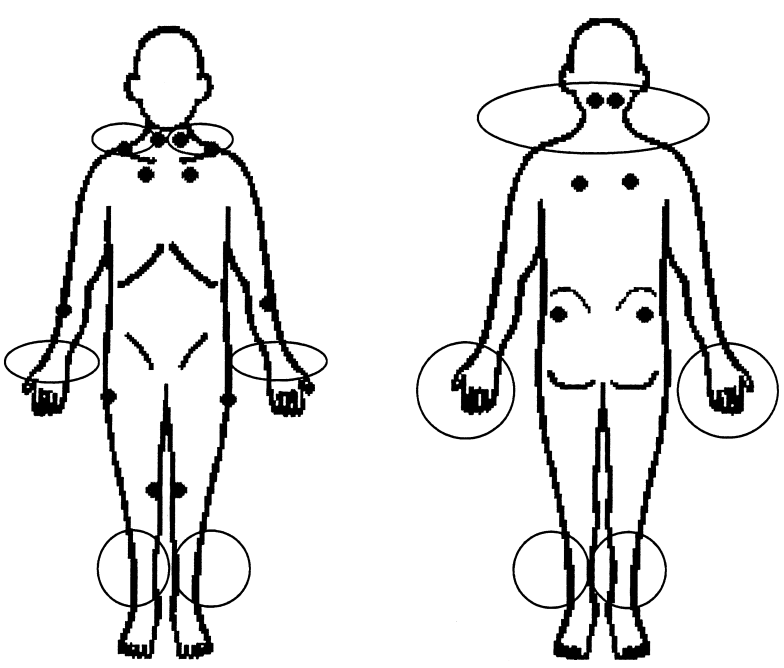

図 1 症例の疼痛の部位

○繊維筋痛症の圧痛点 ○疼痛の強い部位

に一致しない全身の疼痛があり，とくに左右の手背 部, 手関節, 頸肩腕部, 足関節部に強かった。線維 筋痛症の圧痛点はすべて陽性であった。

腱反射は両側上肢正常, 両側下肢膝蓋腱・アキレ 又腱反射低下, 病的反射なし。筋力低下なし。明ら かな巧緻運動障害, 痤性に伴う歩行障害なし。

両上肢 - 体幹 - 両下肢の広い範囲に軽度知覚鈍麻 を認めた。

\section{検㚗所見}

入院時の血液生化学検査所見を表 1 に示した。高 脂血症以外，大きな異常を認めなかった。

頸椎 X-p では C 3, C 4 すべりとびまん性に変形 性脊椎症性変化を認めた。

頸椎 MRI ではC $3 / 4, \mathrm{C} 4 / 5, \mathrm{C} 5 / 6$ レベル の軽度春柱管狭窄を認めた。腰椎 MRI は異常なし。

シルマーテストで右 $5 \mathrm{~mm}$, 左 $4.5 \mathrm{~mm}$ と涙液分泌 減少あり。抗 SSA 抗体 $(-)$, 抗 SSB 抗体 $(-)$ 。

\section{東洋医学的所見}

自覚症状では，全身の疼痛は夏場や入浴などで身 体が温まると増悪する。口渴，のぼせがあり，1日 2 リットルの牛乳を飲む（なお，飲水量としては， 牛乳以外にもペットボトルなどからの飲水や食事時 の水分摂取を合わせると, 牛乳を含め 3 リットル/ 日はあったと考えられる)。食事の度に軟便がある。 頻尿・夜間尿は見られず，尿不利も認めない。

他覚所見では, 皮膚は湿潤で, 自汗の傾向あり。 脈候は浮沈中間, 数遅中間 -やや弱 ·小中間 - や や弦・やや渋。舌候は暗赤色, 亀裂を認め, 乾燥し た白苔に被われていた。 
表 1 症例の入院時血液検査所見

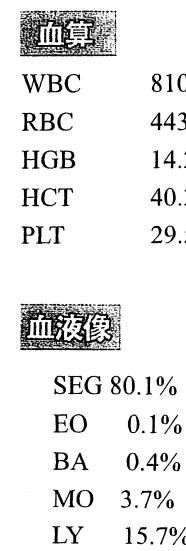

\section{su侅学}

$\begin{array}{lrl}\text { TP } & 6.6 & \mathrm{~g} / \mathrm{dL} \\ \text { GOT } & 18 & \mathrm{U} / \mathrm{L} \\ \text { GPT } & 27 & \mathrm{U} / \mathrm{L} \\ \text { LDH } & 182 & \mathrm{U} / \mathrm{L} \\ \text { ALP } & 232 & \mathrm{U} / \mathrm{L} \\ \gamma \text {-GTP } & 67 & \mathrm{U} / \mathrm{L} \\ \text { T-BIL } & 0.4 & \mathrm{mg} / \mathrm{dL} \\ \text { UA } & 6.1 & \mathrm{mg} / \mathrm{dL} \\ \text { UN } & 19 & \mathrm{mg} / \mathrm{dL} \\ \text { CRE } & 0.59 & \mathrm{mg} / \mathrm{dL} \\ \text { T-CHO } & 272 & \mathrm{mg} / \mathrm{dL} \\ \text { TG } & 867 & \mathrm{mg} / \mathrm{dL} \\ \text { HDL } & 52 & \mathrm{mg} / \mathrm{dL}\end{array}$

$\begin{array}{lrl}\mathrm{NA} & 141 & \mathrm{mEq} / \mathrm{L} \\ \mathrm{K} & 4.3 & \mathrm{mEq} / \mathrm{L} \\ \mathrm{Cl} & 113 & \mathrm{mEq} / \mathrm{L} \\ \mathrm{CA} & 9.8 & \mathrm{mg} / \mathrm{dL} \\ \mathrm{CHE} & 376 & \mathrm{U} / \mathrm{L} \\ \mathrm{AMY} & 88 & \mathrm{mg} / \mathrm{dL} \\ \mathrm{CPK} & 136 & \mathrm{U} / \mathrm{dL} \\ \mathrm{GLU} & 121 & \mathrm{mg} / \mathrm{dL} \\ \mathrm{CRP} & 0.1 & \mathrm{mg} / \mathrm{dL} \\ \mathrm{RF} & 14 & \mathrm{IU} / \mathrm{mL} \\ \mathrm{TSH} & 0.859 & \mu \mathrm{IU} / \mathrm{mL} \\ \mathrm{FT}_{3} & 3.16 & \mathrm{pg} / \mathrm{dL} \\ \mathrm{FT}_{4} & 0.99 & \mathrm{ng} / \mathrm{dL}\end{array}$

\section{ming}

抗核抗体 $( \pm)$

（HOMO 40 倍）

(SP 80 倍)

抗 DNA 抗体 $0.00 \mathrm{IU} / \mathrm{ml}$

抗 SSA/RO 抗体 (-)

抗 SSB/LA 抗体 (-)

白虎加桂枝湯 (石膏 $15 \mathrm{~g}$ 、知母 $5 \mathrm{~g}$ 、粳米 $9 \mathrm{~g}$ 、甘草 $2 \mathrm{~g}$ 、桂皮 $4 \mathrm{~g}$ )

石膏 $30 \mathrm{~g}$ 、知母 8 g人增量 人参3g 追加
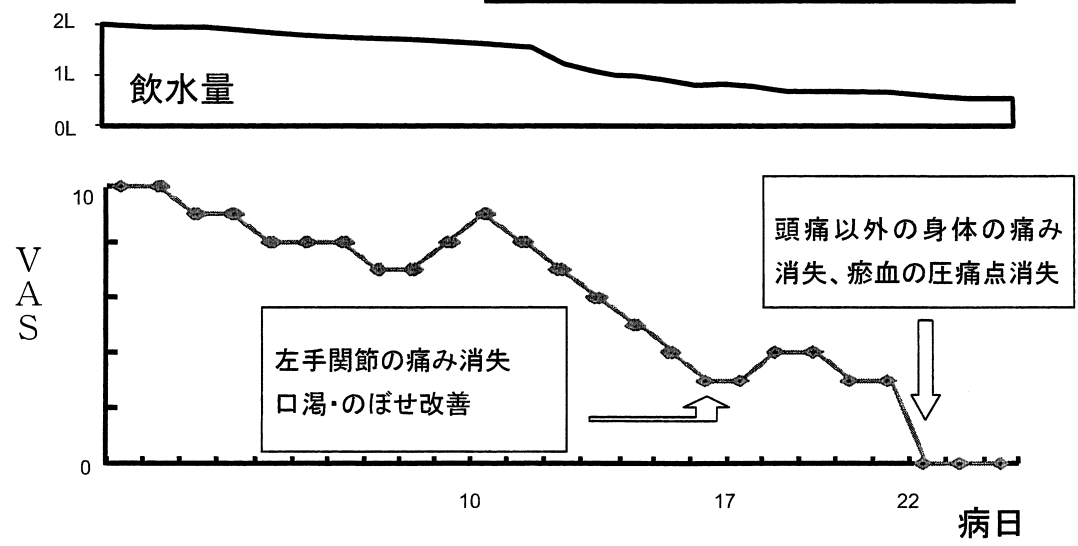

図 2 入院後経過

腹候は腹力やや軟弱, 右胸脇苦満, 心下㿋鞕, 左 右臍傍・臍下・右回盲部の圧痛を認めた。

\section{入院後経過}

3 カ月以上続く全身の疼痛と, 線維筋痛症の圧痛 点がすべて陽性であったことから，線維筋痛症と診 断した。

臨床経過を図 2 に掲示した。温まると増悪する全 身の疼痛という症状及び著しい口渴，多飲から，身 熱の甚だしい状態と考え, 白虎加桂枝湯（石膏 $15 \mathrm{~g}$, 知母 $5 \mathrm{~g}$ ，粳米 $9 \mathrm{~g}$ ，桂皮 $4 \mathrm{~g}$ ，甘草 $2 \mathrm{~g}$ ）を開始した。 また，高脂血症のため牛乳の摂取をやめ水や扮茶を 飲むように指導した。第10病日, 疼痛および口渴に 変化はなく, 身熱の状態が依然として強いと判断さ れたため, 石亳を $15 \mathrm{~g}$ から $30 \mathrm{~g} へ$, 知母を $5 \mathrm{~g}$ から $8 \mathrm{~g}$ 一増量し, さらに人参を $3 \mathrm{~g}$ 追加した。第 17 病 日より左手関節の痛みと口渇，のぼせの改善が見ら れ，飲水量は 1 日 1 リットルに減少，排便も 1 日 1
回の普通便になった。第22病日には頭痛以外の身体 の痛みが消失し, 他覚的には疼血の圧痛点も消失し, 第33病日退院となった。

\section{考察}

線維筋痛症は筋骨格系の疼痛やこわばり, 疲労感 が一般的な症状であり, 他覚所見や臨床検査に異常 が検出されない。約30\%程度の患者は精神疾患と診 断され，その多くがうつ病，不安症，身体化障害， 心気症であるが，とくに精神医学的問題がない患者 にも生じる。痛みは首, 肩, 腰など一箇所からはじ まって広がっていき，灼熱様，こわばり感，うずき， などと表現される。関節痛や関節の腫脹感を訴える こともあるが, 他覚的関節所見はほぼ正常範囲内で ある。身体所見の特徵は, 健常人よりも痛みを感じ る特異的な圧痛点が存在することである

診断は1990年のアメリカリウマチ学会の診断基 準 ${ }^{3)}$ が用いられ，3 カ月以上続く広範囲（左半身， 
右半身，上半身，下半身，体軸骨格のすべて）にわ たる筋骨格系の疼痛の既往と, 指による触診で圧痛 点18箇所のうち少なくとも11箇所で陽性になること から診断される。

本症例では全身の疼痛の既往掞よび圧痛点のいず れも満たしており, 線維筋痛症と診断した。なお, 本疾患は筋骨格系の疼痛, 眼の乾燥, 手指の冷感, 疲労といった共通の症状をもつSLE やシェーグレ ン症候群と誤診されることがある。抗核抗体はしば しば陽性であるが，特徵的な症状や結合組織疾患の 特徵が見られない患者での抗核抗体陽性の信頼度は 非常に低い。また甲状腺機能低下症の症状は線維筋 痛症と類似することがあり，また併発することもあ るため, 鑑別は重要である ${ }^{1}$ が，本症例では口渴， 涙液減少は認められたものの血清学的にはシェーグ レン症候群を含む膠原病は否定的で, 甲状腺機能低 下も認められなかった。

漢方医学的に本症例を検討すると, まず，白虎湯 は, 『傷寒論』には,「傷寒, 脈浮滑, 白虎湯之を主 る。诗), 「三陽の合病, 腹滿, 身重く, 以て転側し難 く, 口不仁にして面垢き, 讝語, 遺尿す。汗を発す れば則ち讝語甚だしく，之を下せば則ち額上に汗を 生じ, 手足逆冷す。若し自汗出づる者も, 白虎湯之 を主る。」5)，「傷寒，脈滑にして厥する者は，裏に熱 あるなり，白虎湯之を主る。」」) と記載されており， 裏に熱のある状態に適応となる。本症例では, 腹力 ・脈力ともに弱く, やや虚証で白虎湯の正証とは考 えられなかったが, 温まると増悪するという自覚症 状㧍よび, 著しい口渇, 多飲から, 裏熱の甚だしい 状態と考えられ，白虎湯証と判断した。

次に白虎加桂枝湯は, 『金實要略』に,「陰気孤絶 し, 陽気独り発すれば則ち熱して少気煩冤し, 手足 熱して嘔せんと欲す。名づけて痰瘧という。若し但 だ熱して寒せざる者は, 邪気, 内は心に蔵し, 外は 分肉の間に舎り，人をして肌肉を消䤵せしむ。温瘧 は, その脈平の如く, 身に寒なく, 但熱し, 骨節疼 煩し，時に嘔す。白虎加桂枝湯之を主る。」う)とあり， 骨節疼煩の記載から, 白虎湯証で全身の強い疼痛を 示すものに適応があり, 線維筋痛症にも応用される と考えられる。

また，白虎加人参湯は，『傷寒論』に，「傷寒，脈 浮, 発熱汗無く, 渇して水を飲まんと欲し, 表証な き者は，白虎加人参湯之を主る。」帛と記載され，『金
圓要略』には「太陽の中熱は暍これなり。汗出でて 悪寒し, 身熱して渴す。白虎加人参湯之を主る。」9) と記載されている。「渴して水を飲まんと欲し」，抒 よび「身熱して渇す」との記載から, 白虎加人参湯 は白虎湯証で口渴の著しいものに適応があると考え られる。

本症例では, 裏熱が甚だしく全身の強い疼痛があ ることから，まず白虎加桂枝湯を開始し，その後10 日間症状に改善が認められなかったのは, 身熱の状 態が依然として強いためと判断し, 清熱・滋潤作用 を高めるために白虎加桂枝湯に石亳・知母を増量, さらに激しい口渇に対し人参を加味することで，白 虎加人参湯の方意も加えて症状の改善を認めたもの である。

線維筋痛症に対する漢方薬治療の報告では, 検索

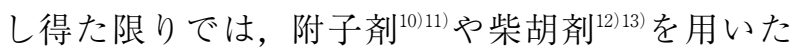
処方のみで, 白虎湯類を使用した報告はなかった。

線維筋痛症に対し, 白虎湯加味方が有効であった 症例を経験した。線維筋痛症で, 温熱刺激により全 身の疼痛が悪化する症例には, 白虎湯類が有効であ る可能性があり，今後は鑑別に入れるべきと考える。

附記 : 本稿の症例に投与した白虎湯加味方の構成と 生薬集散地は以下の通りである。

白虎湯加味方: 石膏 $(30 \mathrm{~g}$, 中国), 知母 $(8 \mathrm{~g}$, 中 国), 粳米 ( $9 \mathrm{~g}$, 日本), 桂皮 ( $4 \mathrm{~g}$, 中国), 甘草 ( 2 $\mathrm{g}$, 中国)，人参 $(3 \mathrm{~g}$, 韓国 $)$

\section{文献}

1 ) 福井次矢監訳：ハリソン内科学書第 2 版（原著第 16版), 2110-2112, メディカル・サイエンス・イ ンターナショナル, 東京 (2006)

2 ）三浦於菟：痺証，モダンメディシン，20，58-62 (1991)

3 ) Wolfe F, Smythe HA, Yunus MB, Bennett RM, Bombardier C, Goldenberg DL, Tugwell P, Campbell SM, Abeles M, Clark P, et al. : The American College of Rheumatology 1990 Criteria for the Classification of Fibromyalgia., Arthritis Rheum. 33， 160-72 (1990)

4 ) 大塚敬節 : 臨床応用傷寒論解説, 352, 創元社, 大阪 (2003)

5 ）大塚敬節：臨床応用傷寒論解説，371, 創元社, 大阪 (2003) 
6 ）大塚敬節：臨床応用傷寒論解説， 459, 創元社, 大阪 (2003)

7 ）大塚敬節主講 : 金貴要略講話, 95, 創元社, 大阪 (2006)

8 ）大塚敬節：臨床応用傷寒論解説, 341, 創元社, 大阪 (2003)

9 ) 大塚敬節主講 : 金圓要略講話, 70 , 創元社, 大阪 (2006)

10）渡辺徹也, 齋藤洋一, 久保田康弘, 河嶋亨 : 漢方 併用による心身医学的治療が有効であった線維筋 痛症の 1 症例，痛みと漢方，14-18（2004）
11）小暮敏明, 巽武司, 佐藤浩子, 伊藤克彦, 田村遵 一, 関矢信康, 並木隆雄, 寺澤捷年 : 和漢薬治療 が奏効した線維筋痛症の二症例, 日本東洋医学雑 誌， 58(1)，61-67（2007）

12）小野静一：線維筋痛症に対する SSRI または SNRI と柴胡加竜骨牡蚛湯の併用の経験, 痛みと漢方, 81-83 (2006)

13）永田勝太郎，岡野寛，喜山克彦，長谷川拓也，広 門靖正, 大柣千佳, 青山幸生：不可解な愁訴を訴 えた慢性疼痛・慢性疲労の 1 例 $(\mathrm{ME} / \mathrm{CFS})$, 痛 みと漢方，62-66（2006） 